\title{
Intra-oral surgical access for the treatment of bilateral submandibular sialolithiasis: case report
}

\author{
Ricardo Martins ${ }^{a}$, Carlos Augusto Ferreira Alves ${ }^{a}$, Edson Martins de Oliveira Junior ${ }^{a}$, \\ Fernando Melhem Elias ${ }^{a, b}$, Antônio Carlos de Campos $^{a, b}$
}

Martins R, Alves CAF, Oliveira Junior EM, Elias FM, Campos AC. Intra-oral surgical access for the treatment of bilateral submandibular sialolithiasis: case report. Autopsy Case Rep [Internet]. 2012;2(2):37-41. http://dx.doi.org/10.4322/ acr.2012.015

\section{ABSTRACT}

Sialolithiasis is a disease that affects the salivary glands. It is characterized by the presence of calcified structures within the duct system or within the glandular parenchyma. Those calculi, or sialoliths, can obstruct normal salivary flow, potentially leading to infectious sialadenitis, with pain, local swelling, and purulent discharge. Treatment typically consists of the surgical removal of the calculus, often in conjunction with sialoadenectomy. The authors report an atypical case of bilateral submandibular gland sialolithiasis treated conservatively, using intra-oral access to remove the calculi.

Keywords: Salivary gland calculi; Submandibular gland; Surgical procedures, Operative.

\section{INTRODUCTION}

Salivary duct calculi, also known as sialoliths, constitute the leading cause of salivary gland obstruction. Sialoliths can occur in the glandular parenchyma or in the salivary duct system, obstructing the flow of saliva and causing episodes of local pain and edema, especially during meals. Sialoliths can be single or multiple, can be unilateral or bilateral, and can vary in shape and size. They affect approximately $1.2 \%$ of the population, and the most commonly affected site is the submandibular gland (involved in approximately $83 \%$ of cases), followed by the parotid gland (in 10\% of cases), and the sublingual gland (in $3 \%$ of cases). ${ }^{1}$

Although some etiological aspects remain unknown, anatomical and biochemical components are certainly involved, ${ }^{2}$ leading to calcium salt deposition around accumulations of organic debris in the lumen of the duct or glandular parenchyma. This organic debris consists of condensed mucus, bacteria, desquamated epithelial cells, or foreign bodies. $^{3,4}$

The salivary flow obstruction caused by sialoliths can lead to salivary gland infection, which is known as sialolithiasis. As previously mentioned, sialolithiasis is most commonly seen in the submandibular glands, which is due to the anatomical features of these glands-including the fact that the trajectory of the duct is long and tortuous, running counter to the force of gravityand to the fact that the secretion produced by the glands is predominantly mucous. ${ }^{5}$

Although the diagnosis of sialolithiasis is primarily based on clinical findings, diagnostic

\footnotetext{
a Department of Dentistry - Hospital Universitário - Universidade de São Paulo, São Paulo/SP - Brazil.

${ }^{\mathrm{b}}$ Department of Surgery - Prosthesis and Maxillofacial Trauma - Faculdade de Odontologia - Universidade de São Paulo, São Paulo/SP - Brazil.
}

Copyright $\odot 2012$ Autopsy and Case Reports - This is an Open Access article distributed of terms of the Creative Commons Attribution NonCommercial License (http://creativecommons.org/licenses/by/3.0/) which permits unrestricted non-commercial use, distribution, and reproduction in any médium provided article is properly cited. 
imaging methods include panoramic radiographs, occlusal radiographs, sialography, ultrasound, and computed tomography (CT). ${ }^{6}$ Conventional treatment depends on the location of the sialolith and can be intra- or extra-oral. Small sialoliths located near the orifice of the submandibular duct can be removed by manipulation or by submandibular duct catheterization and dilatation. Sialoliths located up to the anterior half of the duct are generally treated by conservative surgery, preferably via an intra-oral approach. ${ }^{7}$ In cases of large sialoliths, particularly those in the glandular parenchyma, the calculus and the gland should be removed, which is generally done via an extra-oral approach.

\section{CASE REPORT}

A 34-year-old male patient with a good overall health status (American Society of Anesthesiologists physical status 1, i.e., normal healthy) reported an 18-month history of swelling and pain (particularly during meals) in the floor of his mouth. He also reported mild dry mouth and spontaneous pus discharge under the tongue. Clinical examination revealed bilateral swelling in the submandibular region, together with submandibular lymphadenopathy, purulent discharge in the sublingual caruncle (upon milking of the right submandibular gland), and slightly reduced salivary flow. Palpation of the floor of the mouth revealed two sialoliths, one on each side, with no local swelling (Figures 1A and 1B). After the initial evaluation, we requested a CT scan of the submandibular region and started the patient on a 15-day course of antibiotic therapy with oral clindamycin.

The CT scan showed an image that was consistent with two sialoliths of approximately $10 \mathrm{~mm}$ in diameter each. The sialoliths were lodged near the orifice (in the hila) of both submandibular salivary glands (Figures $2 \mathrm{~A}$ and $2 \mathrm{~B}$ ).

After a clinical diagnosis of bilateral submandibular sialolithiasis had been established, the proposed treatment was intra-oral removal of the sialoliths, with the primary objective of maintaining submandibular gland function. In case of intra-oral removal failure, right sialoadenectomy (removal of the entire submandibular gland) has to be performed, the left gland being maintained and a further procedure being employed in order to remove the sialolith on that side.

With the patient under general anesthesia and after careful palpation to determine the exact location of the calculi, incisions were made in the floor of the mouth, immediately above the calculi, followed by blunt dilatation, clamping, and removal of both calculi. As shown in Figures $3 \mathrm{~A}$ and $\mathrm{C}$, the incisions were closed with a single layer of absorbable polyglycolic acid sutures (Vicryl 3.0; Ethicon, Inc., Somerville, NJ, USA).

On postoperative day 1 , no motor or sensory impairment was observed by us or reported by the patient, who was therefore discharged on antibiotics. At this writing, 6 months after the surgical procedure, the patient was under outpatient follow-up, with no pain or clinical signs of submandibular gland obstruction or infection. In addition, submandibular gland function and salivary function were preserved (Figure 4).

\section{DISCUSSION}

Sialolithiasis is the most common disease of the major salivary glands and is the leading cause of major salivary gland dysfunction. ${ }^{8}$ The main
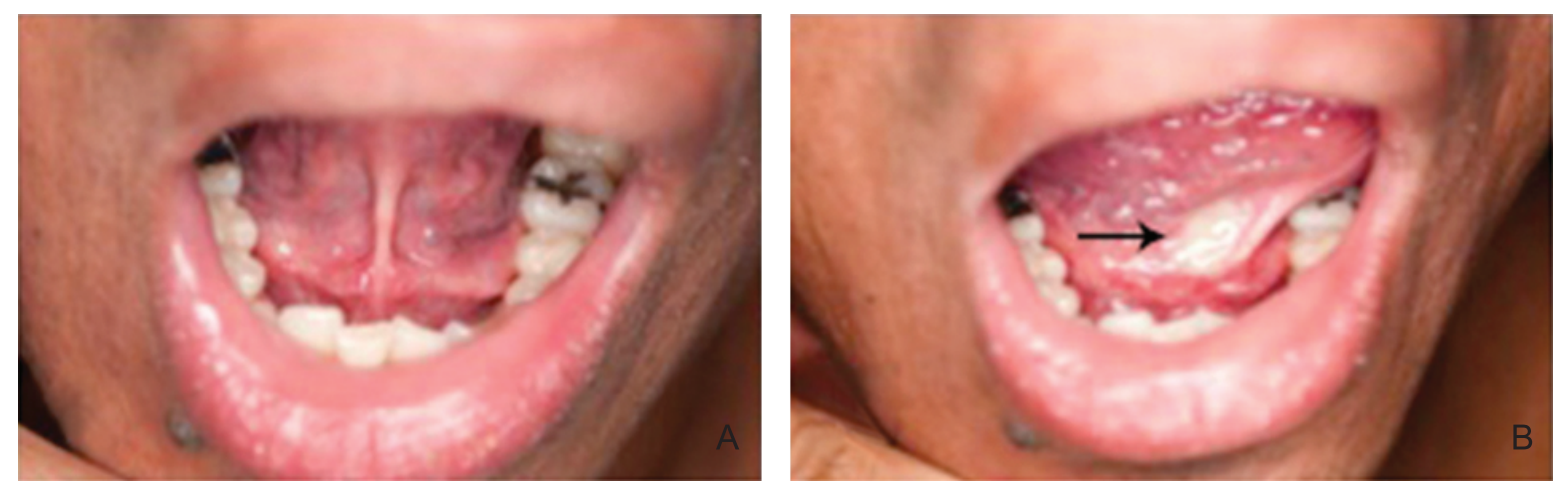

Figure 1 - A - Initial clinical appearance; B - Purulent discharge in the right sublingual caruncle upon milking of the submandibular gland (arrow). 
feature of sialolithiasis is the formation of calcified structures (i.e., sialoliths) in the duct system or glandular parenchyma. ${ }^{3}$

Sialoliths, also known as salivary stones, can affect individuals of all ages. However, they are more common in youths and middle-aged adults. Sialoliths are rarely seen in children. Sialoliths can affect the submandibular gland (in $80-90 \%$ of cases), the parotid gland (in $5-20 \%$ of cases), and the sublingual gland (in $1-2 \%$ of cases). They rarely affect the minor salivary glands. ${ }^{9}$ It is estimated that sialolithiasis affects 12 of every 1,000 adults.

In the present case, the sialoliths were lodged in both submandibular glands, specifically in the glandular hilum, which, according to the literature, is a commonly affected site. However, bilateral involvement is considered rare.$^{3,5,9}$ According to Shafer et al. ${ }^{10}$ and Nahiele et al., ${ }^{6}$ sialolithiasis primarily affects males, as in the present case.

Various theories have been put forward in an attempt to explain the etiopathogenesis of sialolithiasis. According to Epker, ${ }^{11}$ the disease results from calcium salt deposition around a nidus of organic material, consisting of altered salivary mucin, bacteria, and desquamated epithelial cells. The formation of salivary duct calculi occurs in two phases. In the first phase, the core layer is formed by calcium salt precipitation. In the second, there is deposition of organic and inorganic material. Subsequently, mineralization occurs as a result of calcium accumulation and changes in salivary $\mathrm{pH}$.
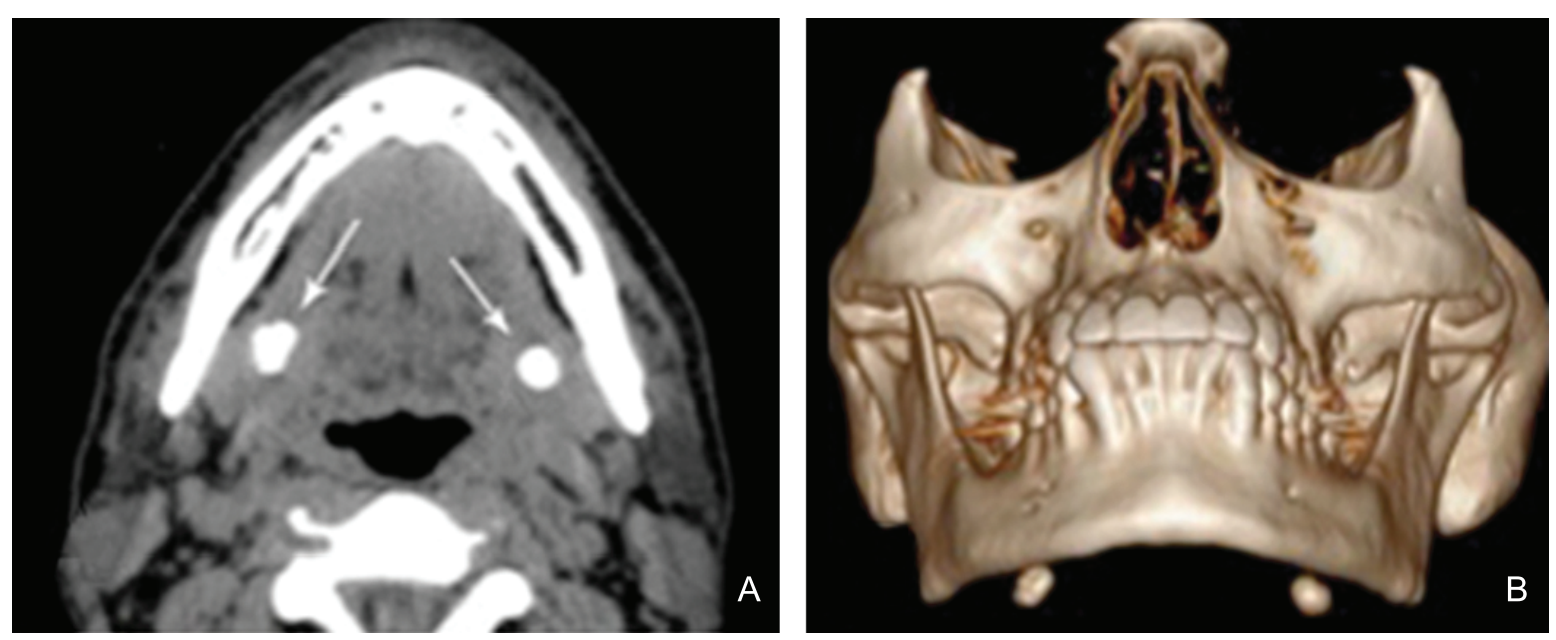

Figure 2 - A - Computed tomography scan showing the presence of bilateral submandibular calculi (arrows), each approximately $10 \mathrm{~mm}$ in diameter; $\mathbf{B}$ - Three-dimensional reconstruction showing the submandibular calculi.
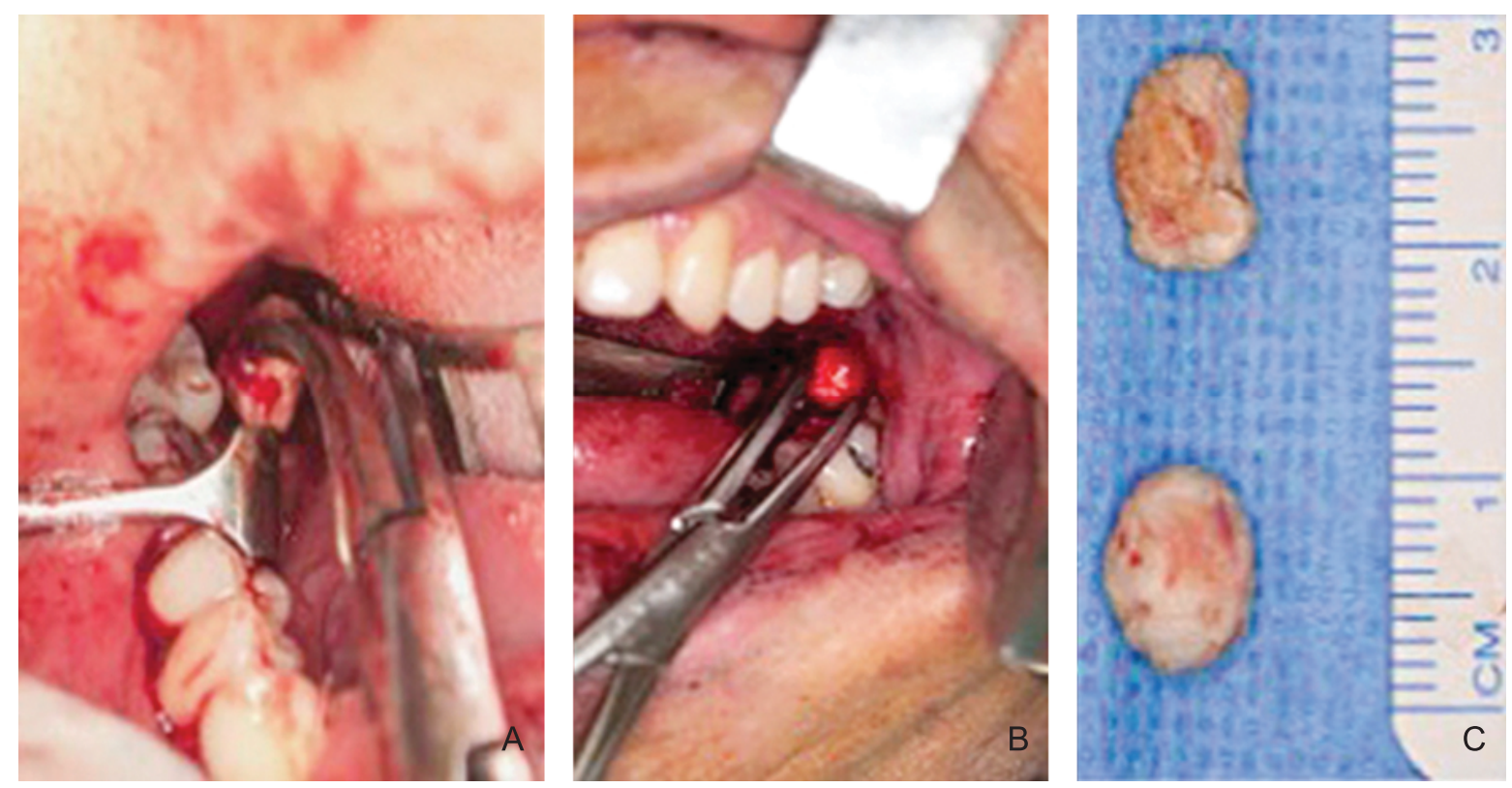

Figure 3 - A and B - Intra-oral removal of the sialoliths; C - the removed sialoliths (one from each side). 


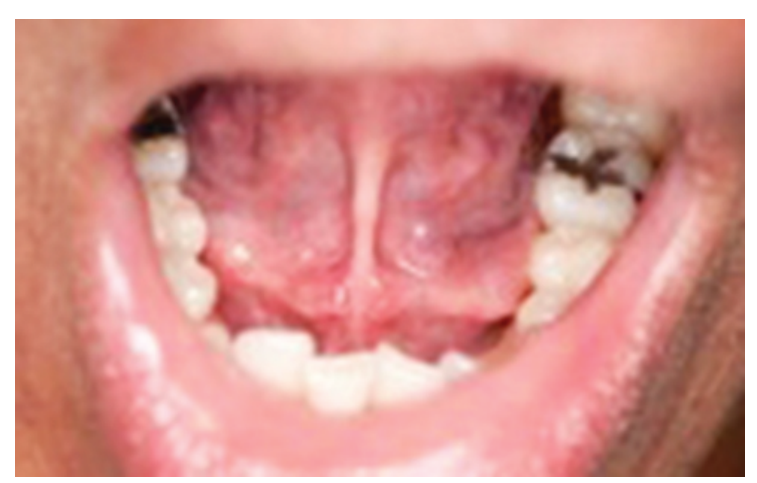

Figure 4 - Photograph taken at postoperative month 6 , showing the absence of infection and the presence of salivary secretion.

The diagnosis of sialolithiasis is based primarily on clinical history and clinical presentation. The vast majority of patients present with pain and swelling in the submandibular gland region, which are due to salivary duct obstruction by the sialolith. Extra-oral palpation of the submandibular region reveals a hard swelling, which can be accompanied by inflammatory lymphadenopathy. The milking of the submandibular gland can result in purulent discharge from the ostium of the gland, as well as in reduced salivary flow.

The differential diagnosis should include obstructive sialadenitis (without sialolithiasis), mumps, and salivary gland tumors. ${ }^{12}$ Approximately $80 \%$ of all sialoliths are radiopaque and can be seen in most radiographic examinations. Panoramic and occlusal radiographs provide good visualization of sialoliths in the submandibular gland. ${ }^{13}$ In the case reported here, because of the presence of bilateral submandibular swelling and because palpation of the floor of the mouth revealed two hard structures (one on each side), CT was requested in order to rule out other diseases. In our experience, CT should be used as the primary imaging test for the differential diagnosis of diseases of the salivary glands, especially because it can show the precise location of sialoliths.

In cases of sialolithiasis, the severity of the symptoms varies with the size and location of the calculus, as well as with the extent of the obstruction. Intraparenchymal sialoliths tend to cause symptoms that are less severe. However, if the duct is occluded, the probability of salivary gland infection is far higher. ${ }^{1}$

Small sialoliths can sometimes be treated conservatively with massage towards the glandular drainage, in order to direct the calculus to the opening of the duct. Other forms of treatment include the use of diet rich in acidic foods or other foods that stimulate saliva production and can therefore expel the calculi from the ducts. ${ }^{14}$

Park et al. ${ }^{15}$ recommend that submandibular calculi be removed intra-orally in order to preserve the gland, especially if the sialolith is palpable distal to the gland. Surgical excision of the affected gland might be required in cases in which the sialoliths are extremely close to the glandular parenchyma, as well as in those in which there are recurrent episodes of salivary gland infection. ${ }^{14}$ According to Torroni etal., ${ }^{16}$ surgical excision of the submandibular gland is a relatively simple procedure that poses little risk to adjacent structures and is of little esthetic consequence. However, we believe that the procedure poses a risk of injury to the marginal mandibular branch of the facial nerve, which can in turn cause motor impairment of the lower lip. Therefore, surgical excision of the affected gland should not be the treatment of first choice.

In the case reported here, both calculi were palpable in the floor of the mouth, what facilitated the surgical access, despite the fact that the sialoliths were located in the glandular hila. Therefore, we chose the intra-oral approach, contrary to the recommendations of Bsou \& Flint, ${ }^{1}$ Quellete \& Stack, ${ }^{17}$ and Gabrielli et al. ${ }^{14}$ Despite the narrow surgical field, the intra-oral approach reduced the possibility of injury to adjacent structures.

\section{CONCLUSION}

In the case reported here, an intra-oral approach via the floor of the mouth proved effective for the removal of two sialoliths located in the initial portion of the submandibular duct (one on each side). Therefore, the intra-oral approach is warranted, particularly in cases in which the sialoliths are palpable. The esthetic results of the intra-oral approach are better than those of the extra-oral approach, the former accompanied by low morbidity.

\section{REFERENCES}

1. Bsoul AS, Flint DJ. Clinical images in oral medicine and maxillofacial radiology: sialolithiasis. Quintessence Int. 2003;34(4):316-7. PMid:12731621. 
2. Yu CQ, Yang C, Zheng LY, Wu DM, Zhang J, Yun B. Selective management of obstructive submandibular sialadenitis. $\mathrm{Br}$ J Oral Maxillofac Surg. 2008;46(1):46-9. PMid:17703856. http://dx.doi.org/10.1016/j.bjoms.2007.06.008

3. Neville BW, Damm D, Allen CM, Bouquot JE. Patologia oral e maxilofacial. 2. ed. Rio de Janeiro: Guanabara Koogan; 2008.

4. Lee LT, Wong YK. Pathogenesis and diverse histologic findings of sialolithiasis in minor salivary glands. J Oral Maxillofac Surg. 2010;68(2):465-70. PMid:20116725. http:// dx.doi.org/10.1016/j.joms.2009.03.041

5. Ellis III E, Hupp JR, Tucker MR. Cirurgia oral e maxilofacial contemporânea. 5. ed. Rio de Janeiro: Elsevier; 2009.

6. Nahlieli O, Neder A, Baruchin AM. Salivary gland endoscopy: A new technique for diagnosis and treatment of sialolithiasis. J Oral Maxillofac Surg. 1994;52(12):1240-2. http://dx.doi. org/10.1016/0278-2391(94)90043-4

7. Oliveira CMB, Mizuno EHF, Favaro JC, Mizuno LT. Cálculo salivar "gigante" (25mm x 15mm): relato de caso. Rev Ciênc Odontol. 2003;6(11):7-11.

8. Williams MF. Sialolithiasis. Otolaryngol Clin North Am. 1999;32(5):819-34. http://dx.doi.org/10.1016/S0030$6665(05) 70175-4$

9. Siddiqui SJ. Sialolithiasis: an unusually large submandibular salivary stone. Br Dent J. 2002;193(2):89-91. PMid:12199129. http://dx.doi.org/10.1038/sj.bdj.4801491

10. Shafer WG, Maynard KH, Barnet ML, Tomich CE. Tratado de patologia bucal. 4. ed. Rio de Janeiro: Guanabara Koogan; 1987. 837 p.
11. Epker BN. Obstructive and inflammatory diseases of the major salivary glands. Oral Surg. 1972;33(1):2-27. http:// dx.doi.org/10.1016/0030-4220(72)90203-4

12. Uluc ME, Vidinli BD, Erdogan N, Gelal F. Giant cystic dilatation that includes multiple sialolithiasis of submandibular gland. Otolaryngol Head Neck Surg. 2006;134(3):533-4. PMid:16500461. http://dx.doi.org/10.1016/j. otohns.2005.03.073

13. Kawata LT, Baldan RCF, Moraes NP, Biazolla ER. Sialolitíase em ducto de glândula submandibular: relato de dois casos clínicos. Rev Odontol Araçatuba. 2006;27(1):14-8.

14. Gabrielli M, Paleari A, Conte Neto N, Silva L, Dantas J. Tratamento de sialolitíase em glândulas submandibulares: relato de dois casos. Robrac: Rev Odontol Bras Central. 2008;17(44):110-16.

15. Park JS, Sohn JH, Kim JK. Factors influencing intraoral removal of submandibular calculi. Otolaryngol Head Neck Surg. 2006;135(5):704-9. PMid:17071298. http://dx.doi. org/10.1016/j.otohns.2006.07.013

16. Torroni AA, Muztazza MC, Bartoli DD, lannetti GG. Transcervical submandibular sialiadenectomia. J Craniofac Surg. 2007;18(3):613-21. PMid:17538327. http://dx.doi. org/10.1097/01.scs.0000249352.43849.04

17. Quellete AL, Slack CL. Shrapnel-induced sialolith - a rare etiology for saladenitis: case report. J Oral Maxillofac Surg. 2003;61(5):636-7. PMid:12730847. http://dx.doi. org/10.1053/joms.2003.50123

\section{Conflict of interest: None}

Submitted on: $2^{\text {nd }}$ January 2012

Accept on: $2^{\text {th }}$ January 2012

Correspondence: Divisão de Odontologia

Av. Prof. Lineu Prestes, 2565 - Cidade Universitária - São Paulo/SP - Brazil

CEP: 05508-000 - Phone: +55 (11) 3091-9290

E-mail: ricardomartins.cirurgiabmf@gmail.com 
